\title{
Pancasila and Indonesia in the Disruptive Era
}

\author{
Kristina Untari Setiawan \\ Universitas Pelita Harapan \\ Tangerang, Indonesia \\ kristina.setiawan@uph.edu
}

\begin{abstract}
As the biggest archipelago in the world, Indonesia must have a foundation of the state, ideology and way of life to bind and unite the whole nation. Pancasila has been proven to be the best foundation of Indonesia that consists of more than 17,000 islands, 300 tribes, and 700 local languages. It can be summarized that the tie is so strong that Indonesia and Pancasila are inseparable. The current situation In the old regime, people had direct communication or wrote letters. Entering the 20th century, technology has developed greatly even though it has not spread equally all around Indonesia. The eastern part is not as advanced as the western part. In the reformation era, digital technology is developing significantly which produces many new occupations as a result of digital enhancement which is called STEM - science, technology, engineering, mathematics. The fast development of science has made internet available in remote places, reaching people widely. However, it is quite unfortunate that there are many negative impacts among the people, a condition that may threaten the unity of Indonesia. The methodology used in writing this paper is qualitative; literature research and interviews of students in Pancasila and Civics classes. The goal of this paper is raising awareness to uphold Pancasila as all aspect of life. The expected result is the presence of truth and justice, kindness and goodness far more than selfishness, hatred, and hypocrisy.
\end{abstract}

Keywords: Pancasila, Indonesia, disruptive era, Christian worldview, Godly character

\section{INTRODUCTION}

The world we live in has entered into a new era of industrial revolution 4.0. Unlike the previous era of the Old Regime, followed by the New Regime, the Reformation Era has significant changes that totally bring blessings as well as confusion for the society. These changes are the impact of the founding of Internet (interconnection networking) in 1990s. As the internet, together with the $\mathrm{Wi}-\mathrm{Fi}$, is made available in many public places and homes, everybody - ready or not - has been bombarded with tons of information, the good and right information and the bad ones (hoaxes). There are cases that people talked privately but have now become public consumptions. Broadcasting businesses such as television and radio channels have programs related to sexual matters, criminal cases, drug abuse, human trafficking, and many more. In every development or creation of new things, there are always positive and negative impacts. Ideally, people are expected to gain many advantages of the new development, because we don't want to be trapped in the cyberspace tragedy that may lead to further damages. However, in the reality, negative impacts have a tendency to take control and ruin the society.

This paper is written to remind the society toward Pancasila and its noble values in order to act wisely in the disruptive era we live in. The writer has a strong belief that the application of Pancasila values will give encouragement, power, and determination to fight against the negative impacts in this disruptive era. The data is gained through online assignments and the recipients are students in Pancasila and Civics classes from the even semester of January - April 2019 and the short semester of May-July 2019. The expected result is that we as Indonesians may cultivate blessings through the growth of social medias. By doing so, Indonesia can be a big nation that give beneficial contributions and impacts for the world.

\section{RESULTS AND DISCUSSION}

\section{A. The positive effects of the internet}

Every finding by men always brings advantages and disadvantages to human beings. This is also true with the finding of the internet. To start, the writer intended to explore the positive effects of the internet and cyberspace activities by going through some literature reviews. The first positive effect is that internet connection, it is very easy to access news and services all around the world. Internet was launched for the first time in Indonesia in 1988 and was used in a limited community since 1992. In the beginning era, only certain places, such as post offices, have internet access. People had to go to the post office and rented a computer there to send emails or surf the websites. As time flies, wi-fi is now available everywhere, even though the internet access in Indonesia is still considered the poorest in the world according to the data collected by Hootsuit, www.cnnindonesia.com, and WeAreSocial.com. Particularly in Indonesia, the massive development of infra structure has reached remote places or islands. They also have the same opportunities of building their communities. With the growth of smartphones, there are many sites and applications that people can download. According to AppAnnie.com, there are at least 30 applications being downloaded and a person uses 10 applications regularly. GOOGLE Search provides all kinds of information, related to economy, politics, social, culture, 
national and international news in seconds. The touch screen technology has enabled people to only touch their smartphones and they will get what they need and want. We can assume that our life is made easier with this advanced technology. The world becomes borderless. Through social medias like Facebook, Twitter, Instagram, Messenger, friends and even soulmates may come from all over the world. In one smartphone, there are all sorts of applications to help us buy, send, order, donate, participate in social events, and get handy solutions of having a ride with reasonable prices. If we try to have a link with Pancasila, the improvement of the social medias give opportunities to all people to have social justice, as stated in the fifth sila: Keadilan Sosial bagi seluruh rakyat Indonesia. Every Indonesian gets equal chances to receive knowledge, financial stability, health stability, and other aspects of life.

Another positive aspect of the internet is the fact that education can be acquired not only in a specific country or a particular campus but people can take online programs from many universities around the globe. Because connection is no longer a problem, there are now well-known universities that start opening master and doctorate degrees online for international students. Lectures and assignments are done through learning sites and video call. This is relevant with the second sila of Pancasila: Kemanusiaan yang adil dan beradab, and article 31 verse 1 of 1945 Constitution that states: "setiap warga negara berhak mendapat pendidikan. True knowledge is highly needed by a person to maximize his/her potentials and bear fruit according to God's calling for him/her. A person who understands and practices justice and dignity can be expected to improve his life and give positive impacts to those around him.

Furthermore, new kinds of jobs emerge in this digital era. On his visit to an elementary school, President Joko Widodo asked a boy what he wanted to be. The boy said that he wants to be a youtuber. The president laughed at the boy's answer. For people from the baby boomer and the $\mathrm{X}$ generation, a job as a youtuber sounds strange, but certainly not weird for the millennial, $\mathrm{Y}$ and $\mathrm{Z}$ generations. A YouTuber, also known as a YouTube personality, YouTube celebrity, or YouTube content creator, is a type of internet celebrity and videographer who has gained popularity from their videos on the video-sharing website YouTube (cited from Wikipedia). This kind of job might be suitable for young people, especially those who are famous in the society and have many followers. When they upload videos and those videos become viral, they get financial compensation by YouTube.

A female friend works as an IT specialist for an international company in the USA. Because of time difference, she works at night while it is morning in the USA. She prefers working like this at home, especially for the purpose of accompanying her old mother. She doesn't have to rush early in the morning and come home late due to bad traffic, accidents, et cetera. In terms of remuneration, she is also well paid. Her salary is in US dollar. This gives opportunities for her to have time to exercise, hang out with friends, and do other social activities. The problem of getting up early, in which many young people struggle to do, can be overcome.

The last positive impact of this internet for this paper is the birth of online stores. Tokopedia was first launched for public on August 17, 2009 by two young entrepreneurs, William Tanuwijaya and Leontinus Alpha Edison (www.Wikipedia.com). It has been a big success to fulfill the vision of "building an ecosystem where everyone, everywhere, can start and find anything they need (www.tokopedia.com). The positive responses from the society and capital injection from big investors even from other countries have allowed Tokopedia to offer all kinds of services. People are trained to search their needs in this online store. Tokopedia's success encouraged others to build their own online malls. We can name some big names: Shopee, Bukalapak, Blibli, Lazada, and many more. TV and radio commercials that we see daily make us want to buy more and more. These online activities give hopes to people to improve their standard of life. Nowadays, we get the information about various traditional clothes, food, handicrafts, and culture in the internet. People can buy beautiful clothes and outfits from each province in Indonesia. Traditional food that had only limited consumers have now received acknowledgement nationally as well as internationally. Wholesale agents in other countries can place orders of all kinds of furniture directly to the producer of the furniture in a small town in Indonesia. Almost every business available has its online access. People can easily find information about tourism objects, tickets of plane, train, bus and ship in the internet. The regulation of Autonomous Region in the 1945 Constitution, article 18, TAP MPR RI no. XV/MPR/1998, U.U. no 32/2004 which was revised by U.U. no $23 / 2014$ have given the local governments rights and obligations to develop their regions by doing various kinds of promotion in social medias. The president, ministers, governors, and mayors have many accounts such as Instagram, Facebook, and Flogs. It is very important for them to give their accountability of what have been done and achieved. New implementations and regulations are also posted in the social media. In fact, we can know whether a certain news is true or fraud from the legitimate websites. If the news is not found in the legitimate websites, then it can be considered as a fraud or hoax. This goodness leads to the application of Sila 3, Persatuan Indonesia, whose main concern is to remind all Indonesian citizens that the unity among the people is unique especially when we realize that we are heterogeneous. Every place has its own tradition that other places don't have, but the spirit inside every heart is that we are one. In fact, Indonesians have reasons to be proud of the diversity as it brings richness and glory that can be shared to the global world. 


\section{B. The Negative Effects of the Internet}

As mentioned above, like a coin that has 2 sides, the internet has 2 effects: positive and negative. It is quite discouraging that what the writer mentioned in the positive side of the internet: easy access to surf the websites, wider opportunities to gain education and degrees, the emergence of new kinds of jobs and cyberspace markets also have their negative impacts, which would be relevant to say that Pancasila values have not been applied wisely or according to its initial purpose.

Easy access to explore the cyberspace at any spots has trapped people to be involved in all sorts of problems that people 30 years ago never talked about. Family matters, from the simple case of stealing and miscommunication to the most complicated cases of divorce, child abuse, online prostitution, human trafficking, drug deployment, and many more have become the people's daily consumption, with not enough effort to find the remedy because they spread like a virus. Students in the university use their gadgets a lot, even in class. It seems like they cannot live without them. Through the writer's observation when conducting classes, there are some examples of how gadgets are used for negative purposes:

1. Gadgets are used to communicate with their friends or family members.

2. Gadgets are used to browse Instagram, Line, Twitter, and to play online games.

\section{Gadgets are used to cheat or plagiarize.}

The use of gadgets mentioned above bring negative effects because they are used in the improper time and place - in class, during lecture. Instead of obeying the class policy, they continue using the gadgets and don't think that they need to pay attention and to be involved in the active learning process. How can this condition be related to Pancasila? The writer wants to suggest that this kind of attitude violates Sila 1, 2, and 5. Sila 1 is Ketuhanan yang maha esa. The fact that God is placed in the first sila should make us aware that every human being in the earth exists because of God's intention. From the Christian worldview, every human being has a cultural mandate from God to be fruitful and increase in number in order to be able to fill the earth and subdue it, rule over every living creature that moves on the ground (Genesis 1:28). Because every person is born for a purpose, it is important that people live their lives according to His purpose. If the students in the writer's classes act unwisely, it would be easy for them to be dragged into negative behaviors which will lead to a fatal destruction, as they don't fully understand their main purpose of going through a higher education. Sila 2 and 5 may also be violated. The advanced technology that creates applications and programs accessible for many, especially the millennials, the $\mathrm{Y}$ and $\mathrm{Z}$ and alpha generation have lead them to become addicted and overwhelmed, missing the ability to discern what is good and noble for them. The threat that people face is that they become more selfish, living in their own world, and losing dignity and wisdom.

Youtube.com provides films, television and radio programs from around the world. We receive tons of good and bad information. Applications like WhatsApp, Messenger, Line, and Instagram may bring far away people closer, but at the same time, create a distance with people who live close to us." Based on the information from www.verywellmind.com, anxiety disorders and depression have become the most common mental illness in the USA. The recent statistics of children and adolescents who are suffering from depression showed that 3.1 million young people in the USA only, ages 12 and 17, have experienced at least one major depressive episode. Furthermore, 19.4 percent of adolescent girls and 6.4 percent of adolescent boys have experienced a major depressive episode, 70 percent of adolescents who experienced a major depressive episode in the past year, experienced a severe impairment, and 60 percent of children and adolescents with depression are not getting any type of treatment.

It becomes a normal scene in many malls to see a core family sitting around a table and each person is busy with his and her own gadget. There is no connection nor fellowship among family members to strengthen the bond of love. The functions of smartphones have changed, too. In the 80's, people used hand phones to call and send short messages. Nowadays, smartphones must have a good camera, with even higher pixels than the regular camera, because people need to do selfie.

Moreover, the internet has negatively caused chaos on the online education. As stated by detik.com in 2015, the Ministry of Research, Technology and Higher Education of the Republic of Indonesia deactivated 243 campuses due to the breaches they made, such as: academic report, the quality of the professors, violation of the law, distant learning without proper legitimation, Weekend classes, the number of students that is over quota, fake certificates, internal conflicts, student transfer without getting a permission from the minister. In the news we also learn that there are fake institutions that offer bachelor programs, master and even doctorate degree using online education. They turn out to be nonexistent. The fact that some people were trapped by their offers shows that the institution's appearance online looks very promising and qualified. There are also people, unfortunately those in power such as members of the DPR, politicians, and celebrities who have fake certificates. They just used their fame and wealth to get their degrees. This condition surely violates Sila 2 . Having a degree in such a way doesn't guarantee that the person has true knowledge that is needed to make him just and civilized. Moreover, the person may be blacklisted for the fraud he is involved with.

The third negative effect of the internet is the increasing rate of cybercrime. Many financial institutions, especially the big ones, have the mobile-banking (M-Banking) services, and the internet hackers make similar M-Banking to deceive customers. 
They use their skills in a corrupt and dishonorable way. Several weeks ago, KOMPAS put on its headline a form of financial fraud that has ensnared middle to low income people. Many are tempted to borrow money via online. They did not particularly use their common sense to look for further information about the loan. A victim, who is a woman with a low salary said that she never imagined to have a debt of several million rupiahs - a big amount of money for her, and received phone calls from debt collector asking her to pay her debt. The terror is not just toward the victim, but also effects other people who are on the reference list. If the consumer finds out that he is about to be cheated and he warns the cyber thief, the latter would normally curses the customer with dirty impolite words.

\section{Result of Observation in Pancasila and Civics Classes}

Pancasila and Civics are compulsory for all university students as decided by the minister of research, technology, and high education no. 03/M/SE/VIII/2017.

Pancasila curriculum at Universitas Pelita Harapan covers fundamental topics such as: Pancasila as the national foundation, Pancasila as the state's ideology, Pancasila as the people's way of life, Pancasila as the Political Ethics. In Civics, students go through topics such as: state, nation, and country, the rights and responsibilities of a citizen, state defense, democracy, human rights, corruption, geopolitics and geostrategy of Indonesia. The main objective that students are expected to embrace is that Pancasila has been a national agreement. No other ideologies should replace Pancasila. Lecturers need to emphasize the importance of applying the values of Pancasila in the daily life, starting from life in a campus that consists of various tribes of Indonesia and other countries. However, it is not an easy task to run these modules, especially to contrast the noble values of Pancasila with the reality that people face every day. It is sad to say that all silas of Pancasila-despite the fact that the values are cultivated within the archipelago and ideally have been rooted in the heart and way of life of all citizens - have experienced violations.

For the assignments in Pancasila class, the writer asked for students' application of each sila and the challenges found among the society. In groups, students made a presentation based on the topics with the expectation that they at least worked together to prepare the slides and to deliver their findings in front of the class. They also had to start the presentation with a national song and all students sang it together. Another task was to make a short video that they uploaded in YouTube. The videos are about the implementation of Pancasila in our daily life. The writer also gave photos of intolerance and corruption and asked students to comment.

For Civics, students had to make reflections after every topic. They could write a prayer, a poem, a summary of what they learned in class. For the final exam, students worked in groups and did service learning projects where they went to various communities and did activities related to Pancasila and Civics.

In the last even semester of 2018/2019, there were 7 groups in Pancasila class and 7 groups in Civics class. In Pancasila class, there were 40 students and 6 students were foreigners from Russia and South Korea. Regarding the task of sharing their reflection about each sila and the challenges they faced, 90 per cent shared about the basic things, as follows:

\begin{tabular}{|c|c|c|}
\hline $\begin{array}{l}\text { SILA 1: Ketuhanan Yang } \\
\text { Maha Esa }\end{array}$ & $\begin{array}{ll}\text { Practices: } \\
- & \text { Pray before meals } \\
\text { - } & \text { Go to the worship places according to each } \\
& \text { religion } \\
\text { - } & \text { Show tolerance toward other people of } \\
& \text { different background and ethnics. } \\
\text { - } & \text { Every citizen may choose his religion/belief. }\end{array}$ & $\begin{array}{l}\text { Challenges: } \\
\text { - } \quad \text { Religions separate people. } \\
\text { - The majority use their religion in their effort of establishing a } \\
\text { religion-based ideology instead of Pancasila ideology. }\end{array}$ \\
\hline $\begin{array}{l}\text { Sila } 2 \text { Kemanusiaan yang } \\
\text { adil dan beradab }\end{array}$ & $\begin{array}{l}\text { - } \quad \text { Treat people equally } \\
\text { - Apply Rights and obligations without } \\
\text { distinction to race, social status, etc. } \\
\text { - } \quad \text { Do not let our rights injure the rights of others }\end{array}$ & $\begin{array}{l}\text { - } \quad \text { Harassment and abuse of children and women still take place } \\
\text { - } \\
\text { Different treatments received by the minority in schools, } \\
\text { hospitals - places that must give equal services to all people } \\
\text { - } \quad \text { A case in which a factory doesn't employ a certain tribe. } \\
\text { - } \quad \text { More people (including university students) use filthy words } \\
\text { and don't feel wrong or guilty saying them }\end{array}$ \\
\hline Sila 3 Persatuan Indonesia & $\begin{array}{ll}\text { - } & \text { Our priority should be toward unity } \\
\text { - } & \text { Public interests are above personal interest } \\
\text { - } & \text { There is no majority-minority. We are all one } \\
\text { from Sabang to Merauke } \\
\text { - } \quad \text { Differences are our treasure to build the whole } \\
\text { nation to become a country that has dignity } \\
\text { and authority. } \\
\text { A good example was the General Election } \\
2019 .\end{array}$ & $\begin{array}{l}\text { - } \quad \text { Different cultures and languages may cause difficulty to unite } \\
\text { - Politicians put their interests or their party's interests above the } \\
\text { public interests and therefore ruin the sovereignty } \\
\text { Many hoaxes in the social medias show that there are people } \\
\text { who don't understand the importance of being one or people } \\
\text { with limited knowledge or education }\end{array}$ \\
\hline $\begin{array}{l}\text { Sila } 4 \text { Kerakyatan yang } \\
\text { dipimpin oleh hikmat }\end{array}$ & $\begin{array}{l}\text { General Election } 2019 \text { as a form of democracy } \\
\text { served as a good example even though there } \\
\text { were problems along the way }\end{array}$ & $\begin{array}{l}\text { - } \quad \text { Bad influences not to participate in the general election. } \\
\text { - } \quad \text { Indoctrination using religion in a false way. Example: } \\
\text { Indonesian's president must be a Moslem. }\end{array}$ \\
\hline
\end{tabular}




\begin{tabular}{|c|c|c|}
\hline $\begin{array}{l}\text { kebijaksanaan dalam } \\
\text { permusyawaratan/perwakilan }\end{array}$ & $\begin{array}{l}\text { Legitimate citizens have their right to elect the } \\
\text { executives and legislative members. } \\
\text { Differences and disputes must always be } \\
\text { solved in deliberation and controlled by } \\
\text { Pancasila democracy. } \\
\text { Decisions are made in a unanimous manner, } \\
\text { and after that a joint action is taken }\end{array}$ & $\begin{array}{l}\text { Decisions are taken based on the majority's vote. The minority } \\
\text { must be silent. }\end{array}$ \\
\hline $\begin{array}{l}\text { Sila } 5 \text { Keadilan sosial bagi } \\
\text { seluruh rakyat Indonesia }\end{array}$ & $\begin{array}{ll}\text { - } & \text { Every citizen must have access to social } \\
\text { justice } \\
\text { - } & \text { Equal access to public services } \\
\text { - } & \text { Machines and online system are available for } \\
\text { all } & \text { Regional autonomy enables local government } \\
\text { to develop the region's potential } \\
\text { - } \quad \begin{array}{l}\text { The current government provides KIS, KIP to } \\
\text { bring welfare to all citizens }\end{array}\end{array}$ & $\begin{array}{ll}\text { - } & \text { Limited resources and facilities in some part of Indonesia make } \\
\text { people unable to gain good education } \\
\text { - } & \text { Corruption is flourishing } \\
\text { - } & \text { Simple cases such as breaking public facilities, littering that } \\
\text { reduce other's opportunity to enjoy and use the facilities and } \\
\text { environment } \\
\text { - } \quad \text { Unequal law enforcement still take place } \\
\text { - } \quad \begin{array}{l}\text { Millennials don't use their freedom wisely. More become } \\
\text { cigarette, drug, or game addicts. }\end{array}\end{array}$ \\
\hline
\end{tabular}

\section{CONCLUSION}

Pancasila has been determined to be the ideology and foundation of N.K.R.I. It is stated in the preamble of the 1945 constitution, paragraph 4. The understanding is that the 1945 Preamble should not be changed for whatever reason. Therefore, as long as Indonesia exists, Pancasila will be the foundation and guidance of the people's conduct. Starting from the acknowledgement that there is one God over all creations, Indonesians uphold and exercise humanity, unity, democracy, and social justice.

For this reason, all people are called to achieve the national's vision and mission to make Indonesia a strong and sovereign country. In order to strengthen the values of Pancasila, there must be continuous efforts made. People need to be reminded of the true application of Pancasila and avoid the disruptive behavior that may lead to separation and disunity.

In his speech in the Youth Congress on October 28, 1874, The first President, Soekarno, said, “"Pancasila janganlah hendaknya hanya dimiliki, akan tetapi harus difahami dan dihayati." In another event he pleaded that Pancasila should live in the heart of every citizen, because by doing so, Indonesia can achieve national welfare and justice.

The government regulation to make Pancasila and Civics compulsory up to university is a right decision, because in the higher education, students can be expected to apply logical thinking in expressing their opinions. Lecturers of Pancasila and Civics are challenged to give practical examples of what are going on in the society and how to relate them with the modules.

Another improvement is the launching of many new rules and regulations, for example regulations related to the I.T.E. (Informasi Transaksi Elektronik) matters. According to the writer, it is important to make people aware that there are consequences if people cause problems or chaos. Every wrong doing will bring people to court. Living in this 21 st century forces us to deal more with robotic systems and regulations. That must be accepted in order to abolish corruption, misbehavior, inequality.

As a person who believes in the Supreme God, the writer would like to share how Christian faith and teaching support all values in Pancasila. The first sila is in accordance with The Holy Bible that teaches: Hear, Israel: The Lord our God, the Lord is one (Deuteronomy 6:4). Furthermore, the One God gives human beings a mandate to be fruitful, fill the earth and subdue it. Human beings are given intuition, talents, and skills to cultivate the earth. When sin occurred, God's beautiful creations experienced a downfall. People with power corrupt. Every person's conducts are sinful and rebellious against God. So, corruption already occurred in the beginning of this world. Adam and Eve did corruption by taking what did not belong to them - they wanted to become like God.

In accordance with the second sila, prophet Isaiah wrote in Isaiah 56:1 "This is what the Lord says: "Maintain justice and do what is right, for My salvation is close at hand." When Jesus lived in this earth, He performed many miracles to confirm His purpose of becoming the Son of man, that is to deliver the people He loves from the evil spirits and to heal them from illnesses. Understanding this concept would enable us to serve others, treat others as we want them to treat us.

In accordance with the third sila, the Holy Bible is full of stories about people from different ethnic groups with God as the Lord of all. The apostle Paul had to minister among the Jewish and Gentiles. The apostle Peter got a vision from God that taught him to treat all nations equally. In the same way, Indonesia that consists of more than 17,000 islands, 300 tribes, and 700 local languages, must have a strong unity. The Youth Pledge on 28 October 1945, declared that there was One Land Indonesia, One Nation - Indonesia, and One National Language - Indonesian. Indonesians must maintain this spirit forever. It is written as well in the 1945 constitution articles 35, 36, 36A, 36B, $36 \mathrm{C}$

In accordance with the fourth sila, the prophet Moses ruled over the Israelites but under him there were local leaders who 
need to be sure that we share only true and valid information and stop the hoaxes that come to us.

\section{REFERENCES}

[1] Anxiety disorders and depression in the USA. Retrieved from www.verywellmind.co

[2] Floriberta Aning. 2017. Lahirnya Pancasila. Yogyakarta: Media Pressindo

[3] Holy Bible. 2006. Jakarta: Lembaga Alkitab Indonesia.

[4] Kecepatan Internet Indonesia ke-2 Terbawah dari 45 Negara. February 3, 2019. Retrieved from www.cnnindonesia.com and www.WeAreSocial.com

[5] Krissantono. 1976. Pandangan Presiden Soeharto Tentang Pancasila. Jakarta:CSIS

[6] Ratusan Kampus Swasta Bermasalah Ditutup Menristekdikti. 19 Februari 2019. Retrieved from www.Detik.com

[7] Sejarah Tokopedia. July 14, 2019. Retrieved from https://en.wikipedia.org/wiki/Tokopedia

[8] Undang-Undang Dasar 1945. Retrieved from www.dpr.go.id 